\title{
Tingkat Serangan Parasit serta Kandungan Logam Berat Merkuri (Hg) pada Kepiting Bakau (Scylla sp) Hasil Tangkapan di Desa Rarongkeu Kec. Lantari Jaya, Kab. Bombana Sulawesi Tenggara
}

\section{Prevalence and intensity of parasite and concentration of Mercury $(\mathrm{Hg})$ on Mangrove Crab (Scylla sp) Catched in Rarongkeu Village, Lantari Jaya District, Bombana Regency, Southeast of Sulawesi}

\author{
Erick Arjuna Aris ${ }^{1)}$, Indriyani Nur ${ }^{2)}$, Muhaimin Hamzah ${ }^{2)}$ \\ 1) Program Studi Ilmu Perikanan Program Pascasarjana Univ. Halu Oleo, Kendari, Indonesia \\ ${ }^{2)}$ Fakultas Perikanan dan Ilmu Kelautan Universitas Halu Oleo, Indonesia \\ Corresponding author ${ }^{*}$ : erickarjoen@yahoo.com
}

\begin{abstract}
This study aims to determine the type of parasite and its infection level and heavy metal concentration of mercury $(\mathrm{Hg}$ ) in mangrove crab (Scylla sp) Catched in Rarongkeu Village, Lantari Jaya District, Bombana Regency, Southeast of Sulawesi. Parasite examination conducted on gill organs while measuring of heavy metals mercury accumulation conducted on several organs such as, gills, meat, blood and the parasite that infect the gills (Octolasmis sp). All parasites found in this study were ectoparasites consisting of Octolasmis sp., And Ascarophis sp that infect the gill organ. Parasite prevalence values range from $50-100 \%$ and intensity range from 69 to 150 Ind / head. The results of measuring heavy metal concentrations were meat $(0.15 \mathrm{mg} / \mathrm{kg})$, gills $(0.087 \mathrm{mg} / \mathrm{kg})$, and blood $(<0.002 \mathrm{ml} / \mathrm{l})$. The concentration is still below the normal threshold. The quality of water obtained shows that water quality is still within the tolerance range to support organism life.
\end{abstract}

Keywords : Scylla sp, Parasite, Prevalence, Intensity, Mercury (Hg)

\begin{abstract}
ABSTRAK
Penelitian ini bertujuan untuk mengetahui jenis parasit dan tingkat serangannya serta kandungan logam berat merkuri (Hg) pada kepiting bakau (Scylla sp) Hasil Tangkapan di Desa Rarongkeu Kec. Lantari Jaya, Kab. Bombana Sulawesi Tenggara. Pemeriksaan parasit dilakukan pada organ insang sedangkan pemeriksaan logam berat merkuri dilakukan pada beberapa organ yaitu, insang, daging, darah dan pada parasit yang menginfeksi insang (Octolasmissp). Seluruh parasit yang ditemukan pada penelitian ini merupakan ektoparasit yang terdiri dariOctolasmissp.,dan Ascarophisspyang menginfeksi organ insang.Nilai prevalensi parasit berkisar antara 50 $100 \%$ dan intensitas 69 - 150 Ind/ekor. Hasil pemeriksaan konsentrasi logam berat pada daging adalah $(0,15$ $\mathrm{mg} / \mathrm{kg})$, Insang $(0,087 \mathrm{mg} / \mathrm{kg})$, dan darah $(<0,002 \mathrm{ml} / \mathrm{l})$. Kualitas air yang diperoleh menunjukkan bahwa kualitas air masih berada dalam kisaran toleransi untuk menunjang kehidupan organisme.
\end{abstract}

Kata kunci : Scylla sp, Parasit, Prevalensi, Intensitas, Merkuri (Hg).

DOI: http://dx.doi.org/10.33772/jspi.v1n1. 
2 Erik Arjuna Aris et al.

JURNAL SAINS dan INOVASI PERIKANAN/ Journal of Fishery Science and Innovation

Vol. 2, No. 1, 1-9, Januari 2018

\section{PENDAHULUAN}

Salah satu sumber bahan pencemar yang banyak dikaji dampaknya dari proses industrialisasi adalah logam berat. Pencemaran oleh logam berat merupakan masalah besar di lingkungan, terutama di kota dengan tingkat pertumbuhan menengah di negara-negara berkembang. Hal ini disebabkan oleh tidak terkontrolnya tingkat polusi yang disebabkan oleh pertumbuhan industri dan penggunaan peningkatan dalam penggunaan bahan bakar minyak. Selain itu, kontaminasi logam berat juga dapat disebabkan oleh emisi proses industri, transportasi, aktivitas pertanian dan aktivitas domestik (Ismarti et al., 2015).

Di antara beberapa jenis logam berat yang berbahaya dan bersifat toksik yang biasa kita jumpai salah satunya adalah merkuri $(\mathrm{Hg})$. Menurut Rompas (2010), merkuri merupakan salah satu logam berat yang biasa digunakan dalam kegiatan industri dan kegiatan pertambangan. Kegiatan tersebut tentu akan berdampak pada lingkungan sekitar khususnya lingkungan perairan akibat dari buangan limbah dari hasil olahan. Di samping itu, bahaya lain dari logam berat ini adalah merkuri bisa masuk dan terakumulasi dalam tubuh organisme melalui kulit, insang dan saluran pencernaan yang berdampak pada kerusakan jaringan dan organ pada organisame (Widodo, 2012). Hal ini tentu akan memberikan dampak negatif pada organisme perairan yang hidup di wilayah tersebut.

Kasus pencemaran pernah terjadi di beberapa tempat di Indonesia. Sebagai contoh, sungai Kahayan merupakan salah satu sungai besar yang berada di Kalimantan. Sungai ini diduga mengalami pencemaran logam berat terutama merkuri. Berdasakan penelitian yang telah dilakukan, kadar merkuri pada air sugai ini sudah mencapai angka 5 ppb dimana angka ini sudah melewati ambang batas yang telah ditentukan (Murtini \& Peranginangin, 2006).

Kasus pencemaran logam berat juga pernah terjadi di daerah Kalimantan Barat. Badan Pengendalian Analisis Dampak Lingkungan Hidup (Bapedalda) Kalimantan Barat tahun 2006, menyimpulkan bahwa kualitas Sungai Kapuas sudah tercemar berat oleh logam merkuri dari limbah buangan penambangan emas. Titik pengambilan seperti di hilir Sungai Landak, Siantan Hulu, Muara Kapuas di Jungkat, dan Muara Sungai Sudarso, secara keseluruhan kadar merkurinya bahkan menunjukkan angka 40 ppb atau 40 kali batas normal.

Pencemaran logam berat tidak hanya mempengaruhi organisme akuatik, seperti ikan, kepiting, udang dan lain sebagainya, namun pencemaran juga dapat mempengaruhi parasit atau organisme yang hidup pada organisme yang terpapar pencemaran tersebut. Beberapa hasil penelitian menjelaskan bahwa jenis parasit tertentu besifat sensitif terhadap perubahan lingkungan, dan beberapa jenis parasit lain lebih bersifat resisten terhadap perubahan lingkungan daripada inangnya, dan ada juga jenis parasit yang cenderung meningkat jumlah individunya dalam kondisi lingkungan yang tercemar (Sures, 2004).

Berdasarkan hasil dari beberapa penelitian menjelaskan bahwa keberadaan parasit jenis tertentu pada organisme yang terpapar polutan dapat menimbulkan dampak akumulasi juga terhadap parasit tersebut sehingga memiliki potensi untuk dijadikan sebagai salah satu bioindikator pencemaran logam berat di perairan khususnya dalam hal keterkaitan hubungan antara parasit dengan polutan itu sendiri (Huspeni \& Lafferty, 2004; Sures, 2006; Vidal et al., 2009). Keterkaitan hubungan tersebut bersifat komplikatif dan pada intinya melibatkan dua fenomena yang ada, yaitu fenomena parasitisme yang dapat mengurangi kemampuan inang dalam mendetoksifikasi polutan yang bersifat toksik atau keberadaan polutan yang bisa meningkatkan atau menurunkan prevalensi dan intensitas dari beberapa jenis parasit (Ugokwe \& Awobode, 2015).

Penelitian ini bertujuan untuk mengetahui pengaruh paparan logam berat merkuri $(\mathrm{Hg})$ terhadap proses bioakumulasi pada kepiting bakau (Scylla sp), untuk mengetahui jenis parasit dominan yang menginfeksi kepiting bakau (Scylla sp) dan untuk mengetahui kemungkinan potensi parasit sebagai bioindikator pencemaran logam berat merkuri. Selain itu, Untuk mengetahui akumulasi merkuri pada beberapa organ pada inang (daging dan insang) dan juga pada hemolimph. Informasi ini bermanfaat untuk keamanan pangan bagi masyarakat sekitar.

\section{METODE PENELITIAN}

\section{- Waktu Dan Tempat}

Penelitian ini dilaksanakan pada bulan Juni November 2017. Penelitian ini terbagi menjadi dua tahap yaitu, tahap sampling lapangan dan 
pengamatan laboratorium. Sampling lapangan dilaksanakan di Desa Rarongkeu, Kec Lantari Jaya, Kabupaten Bombana, sedangkan pengamatan laboratorium yang berupa pemeriksaan kandungan merkuri pada organ target hewan uji bertempat di Laboratorium Kimia Terpadu Institut Pertanian Bogor.

\section{- Prosedur Penelitian}

Penelitian ini dilakukan dengan menggunakan beberapa tahapan, yaitu tahap pertama pengambilan sampel kepiting bakau (Scylla sp) yang diperoleh dari hasil tangkapan alam. Tahap ke dua yaitu pemeriksan parasit pada hewan uji yang akan dilakukan di Laboratorium FPIK Universitas Halu Oleo dan tahap selanjutnya adalah pemeriksaan akumulasi logam berat pada beberapa sampel uji yang dilakukan di Laboratorium Kimia Terpadu Institut Pertanian Bogor.

\section{- Pengambilan Sampel}

Sampel hewan uji kepiting bakau (Scylla sp) diambil dari hasil tangkapan nelayan yang melakukan penangkapan di sekitar wilayah Desa Rarongkeu, Kecamatan Lantarai Jaya, Kabupaten Bombana, Sulawesi Tenggara. Ukuran berat sampel uji yang digunakan adalah kepiting bakau yang berukuran rata - rata di atas 200 gram per ekor. Jumlah sampel penelitian berkisar antara 20 - 25 ekor organisme setiap satu kali pengambilan sampel. Pengambilan sampel dilakukan sebanyak dua kali pada Bulan September dan Oktober dengan selang waktu 30 hari atau satu bulan.

\section{Variabel yang Diamati}

\section{- Prevalensi dan Intensitas}

Data sampel parasit yang ditemukan dari hasil pemeriksaan kemudian dicatat dan untuk tingkat serangan parasit dapat dianalisis dengan menghitung prevalensi dan intensitas parasit (Bush et al., 1997) Perhitungan prevalensi dan intensitas dengan rumus :

- Prevalensi

$$
\mathrm{P}=\frac{\mathrm{N}}{\mathrm{n}} \times 100 \%
$$

Dengan :

$$
\begin{aligned}
& \mathrm{P}=\text { Prevalensi (\%) } \\
& \mathrm{N}=\text { Jumlah sampel ikan yang terserang } \\
& \text { (ekor) }
\end{aligned}
$$

$\mathrm{n}$ = Jumlah sampel ikan yang diamati (ekor)

- Intensitas serangan parasit

$$
\mathrm{I}=\frac{\mathrm{P}}{\mathrm{N}}
$$

Dengan :

I $=$ Intensitas serangan parasit

(individu/ekor)

(individu)

$\mathrm{P}=$ Jumlah parasit yang ditemukan

$$
\mathrm{N}=\text { Jumlah sampel yang terinfeksi (ekor) }
$$

\section{- Pemeriksaan Akumulasi Logam Berat}

Sampel yang digunakan dalam periksaan akumulasi logam berat ini adalah daging dan insang kepiting bakau dan juga parasit yang menginfeksi kepiting bakau tersebut. Pengambilan sampel dilakukan dengan membedah hewan uji secara cermat dan teliti sampai sampel organ target dapat dikeluarkan dengan menggunakan seperangkat alat bedah. Kemudian dilakukan proses isolasi organ target (daging dan insang) dan parasit, setelah itu sampel diambil sebanyak 1-2 gr lalu dimasukkan ke dalam botol steril sesuai dengan kode sampel yang telah ditentukan.

Sampel yang ada dalam botol steril langsung dikeringkan dalam oven dengan suhu $80^{\circ} \mathrm{C}$ selama 24 jam. Sampel yang sudah kering, siap untuk dianalisis. Uji kandungan merkuri pada beberapa sampel tersebut dilakukan di laboratorium dengan menggunakan Spektrofotometer Serapan Atom (AAS), dengan berpedoman pada metode AOAC (2012) yaitu unsur logam berat dalam suatu sampel didestruksi dengan cara pengabuan basah menggunakan campuran asam pekat $\mathrm{HNO}_{3}$ dan $\mathrm{HClO}_{4}$. Penentuan kandungan logam berat terbagi atas beberapa tahap yaitu destruksi, pembacaan absorbans contoh dan perhitungan kandungan logam berat.

\section{- Pemeriksaan Akumulasi Logam Berat pada Hemolimph}

Metode analisis logam merkuri dalam darah kepiting bakau (Hemolimph) dilakukan dengan metode wet ashing. Masing masing sampel sebanyak $2 \mathrm{ml}$ dimasukkan ke dalam Erlenmeyer100 ml, ditambahkan $10 \mathrm{ml}$ HNO3 dan $10 \mathrm{ml} \mathrm{H} 2 \mathrm{SO} 4$. Pemanasan dilakukanperlahan-lahan sampai larutan berwarna gelap. Pereaksi HNO3 ditambahkansambil dilakukan pemanasan selama 5-10 menit hingga larutan berubah warnamenjadi kuning bening. Akuades sebanyak $10 \mathrm{ml}$ ditambahkan dan didinginkan.Larutan ditambahkan dengan $5 \mathrm{ml}$ akuades dan dipanaskan kembali hinggaberasap, 
4 Erik Arjuna Aris et al.

JURNAL SAINS dan INOVASI PERIKANAN/ Journal of Fishery Science and Innovation

Vol. 2, No. 1, 1-9, Januari 2018

kemudian larutan didinginkan dan disaring. Sampel siap dianalisamenggunakan spektrofotometer serapan atom (Atomic Absorbans Spectrofotometry).

\section{Analisis Data}

Data jenis parasit dan nilai akumulasi logam berat yang diperoleh dari penelitian ditabulasi dan dianalisis secara deskriptif. Metode ini merupakan metode yang biasa digunakan untuk menyederhanakan data agar mudah dipahami, penyajiannya yaitu dalam bentuk diagram batang.

\section{HASIL DAN PEMBAHASAN}

\section{Hasil}

\section{Jenis parasit yang Ditemukan}

Hasil pemeriksaan ektoparasit pada kepiting bakau terdapat dua jenis parasit yang ditemukan yaitu Octolasmis sp., dan Ascarophis sp.

Tabel 1. Jenis Parasit yang Ditemukan pada Kepiting Bakau

\begin{tabular}{lllccc}
\hline Jenis Ektoparasit & Gejala Klinis & $\begin{array}{l}\text { Organ } \\
\text { Target }\end{array}$ & $\begin{array}{c}\text { Jml Individu } \\
\text { Sampling I }\end{array}$ & $\begin{array}{c}\text { Jml Individu } \\
\text { Sampling II }\end{array}$ & Total Parasit \\
\hline Octolasmis sp & $\begin{array}{l}\text { Tidak ada gejala } \\
\text { klinis spesifik }\end{array}$ & Insang & 4230 & 2147 & 6377 \\
Ascarophis $\mathrm{sp}$ & $\begin{array}{l}\text { Bagian insang } \\
\text { yang terinfeksi } \\
\text { berwarna hitam }\end{array}$ & Insang & 957 & 2764 & 3721
\end{tabular}
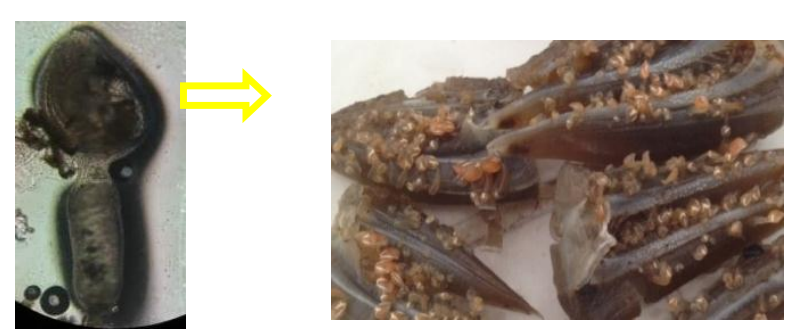

Octolasmis sp

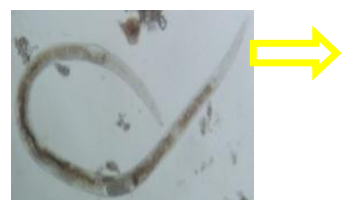

Ascarophis $\mathrm{sp}$

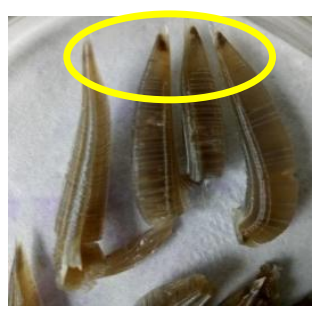

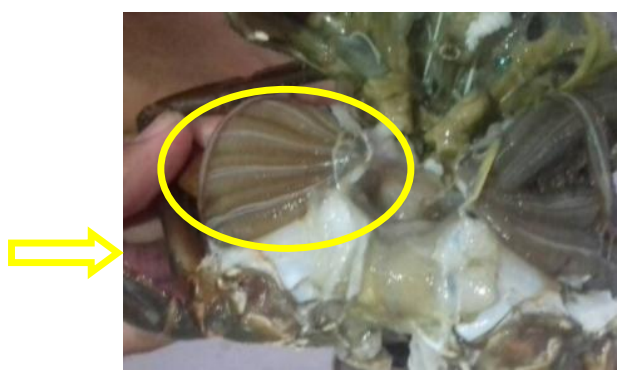

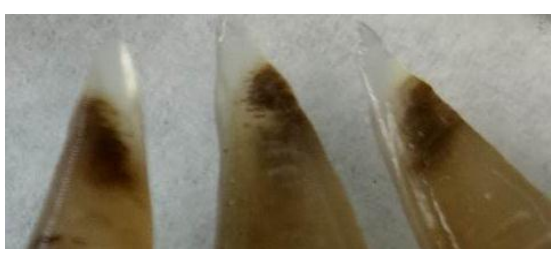




\section{Prevalensi dan Intenitas Parasit}

Berdasarkan data yang diperoleh dari hasil penelitian, nilai pevalensi dan intensitas kedua jenis parasit tersebut cukup tinggi. Tingginya nilai prevalensi suatu jenis parasit dapat memberikan gambaran bahwa parasit jenis Octolasmis sp dan Ascarophis sp. merupakan beberapa jenis parasit yang sering ditemukan menginfeksi kepiting bakau di daerah Bombana khususnya wilayah Desa Lantari Jaya. Hal ini dibuktikan dengan nilai prevalensi atau tingkat angka kejadian infeksi parasit yang cukup tinggi yaitu antara $90-100 \%$ untuk Octolasmis sp dan $50-96 \%$ untuk Ascarophis sp.

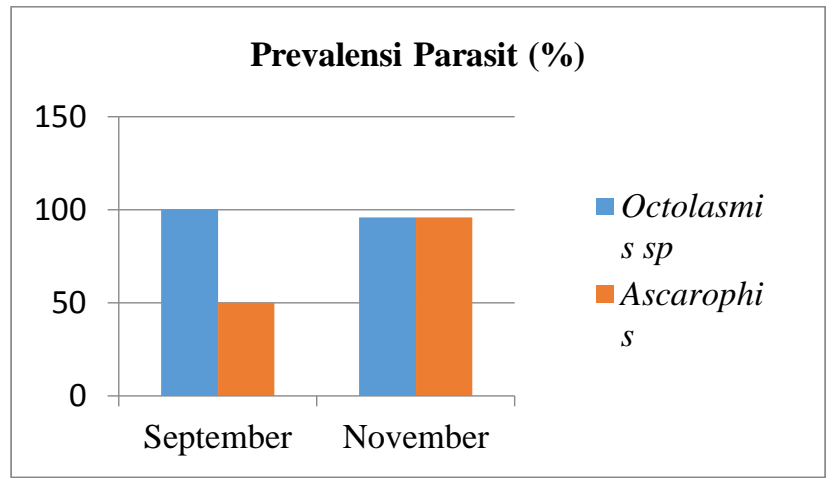

Gambar1. Prevalensi Parasit Octolasmis sp dan Ascarophis sp pada Kepiting Bakau (Scylla sp)di

Desa Lantari Jaya,

Kabupaten Bombana.

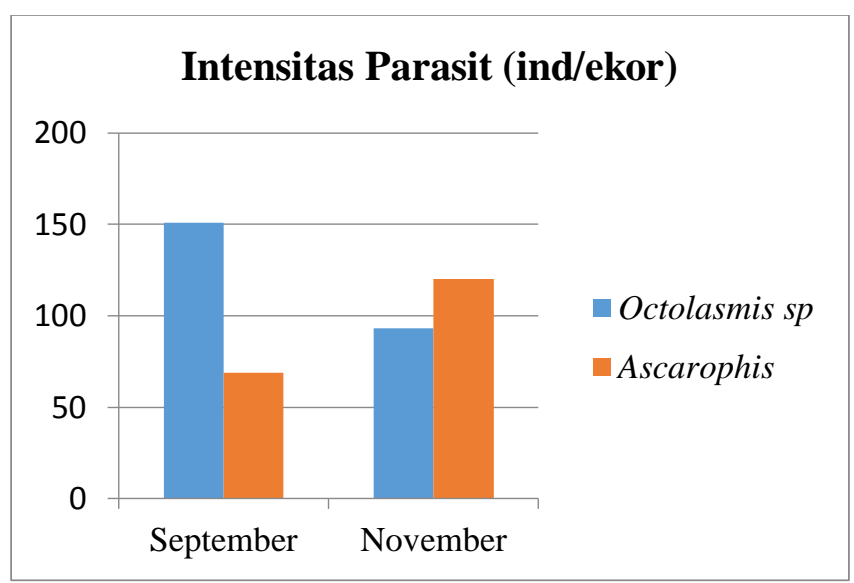

Gambar 2. Intenistas Parasit Octolasmis sp dan Ascarophis sp pada Kepiting Bakau (Scylla sp) di

Desa Lantari Jaya,

Kabupaten Bombana.

\section{Akumulasi Merkuri (Hg) pada Kepiting Bakau}

Hasil yang didapatkan dari pengukuran kandungan merkuri, baik pada biota kepiting dengan organ yang berbeda maupun lingkungannya, diperoleh hasil seperti pada Gambar 4 dan 5 berikut.

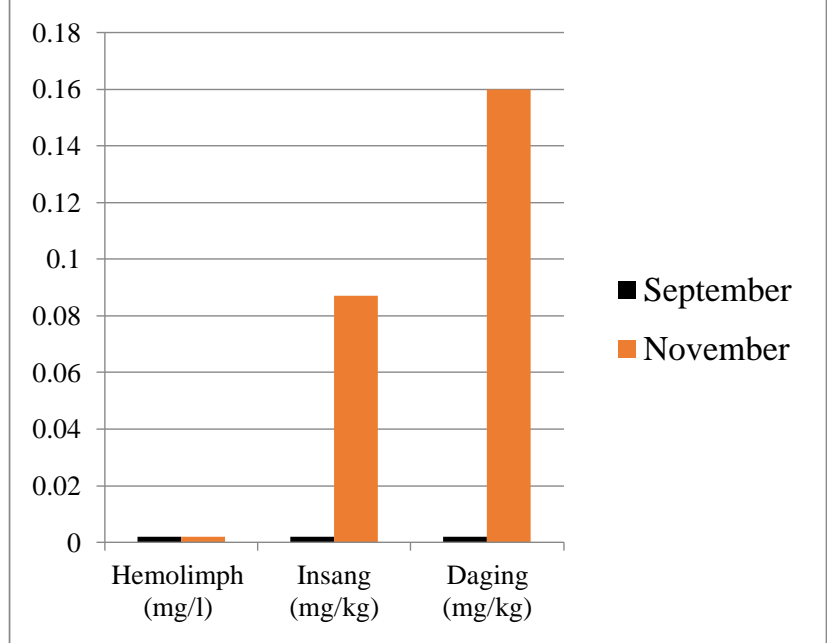

Gambar 3. Diagram Akumulasi Merkuri (Hg) pada

Beberapa Organ Kepiting Bakau (Scylla sp)

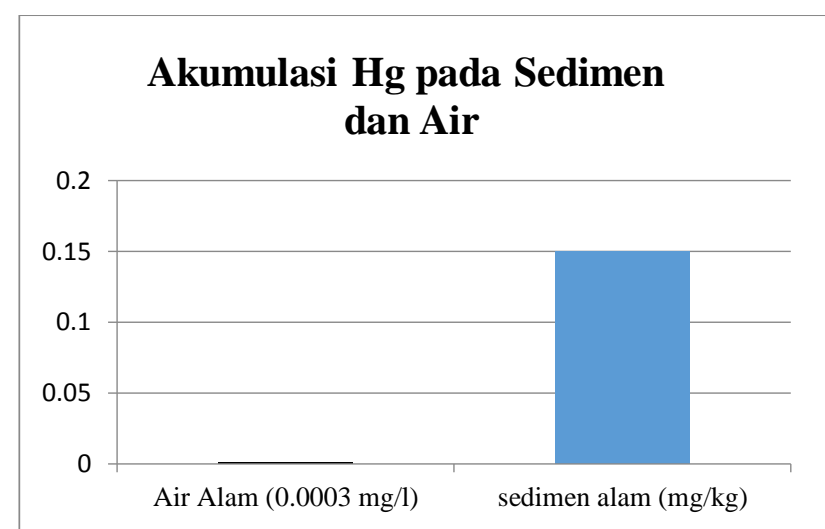

Gambar 4. Diagram Akumulasi Merkuri (Hg) Air dan Sedimen pada Habitat Kepiting Bakau (Scylla $\mathrm{sp)}$

\section{Pembahasan \\ Jenis Parasit}

Octolasmis sp merupakan jenis parasit yang biasa ditemukan menginfeksi hewan crustacea, seperti kepiting bakau. Parasit jenis ini banyak ditemukan menginfeksi insang dengan cara menempel atau menancapkan bagian attachment part pada filamen insang.Proses infeksiparasit ini bisa mengakibatkan kerusakan pada insang dan menganggu proses pernafasan pada organisme. 
6 Erik Arjuna Aris et al. JURNAL SAINS dan INOVASI PERIKANAN/ Journal of Fishery Science and Innovation Vol. 2, No. 1, 1-9, Januari 2018

Peningkatan jumlah atau banyaknya individu parsasit akan sangat berdampak pada parahnya kerusakan pada insang karena jaringan insang yang terinfeksi oleh parasit tersebut akan mengalami kerusakan yang berujung pada ketidaknormalan fungsi insang.

Di samping itu, infeksi parasit ini dapat memberi efek pada inang dengan mengurangi ruang permukaan insang yang bisa berakibat pada rendahnya penyerapan oksigen dan nutrisi atau defisiensi insang untuk menyerap nutrisi dari air. Hal ini tentu akan mempengaruhi kondisi fisiologi ikan khususnya proses respirasi (Ihwan et al., 2014).

Pertumbuhan Octolasmis sp terjadi melalui serangkaian moulting, Siklus hidup spesies Octolasmis meliputi enam nauplius (N1 - N6) dan satu tahap larva cyprid. Rata-rata diperlukan sembilan hari dari kemunculan massa telur pada induk hingga pelepasan larva N1. Pada kondisi tersebut diperlukan 27 hari dari kemunculan pertama massa telur untuk larva cyprid pertama. Perubahan dariN1 - N6 terjadi hanya dalam waktu delapan hari, namun terjadi peningkatan panjang yang cukup besar hingga mencapai duabelas kali.

Dalam jangka waktu tersebut, naupliar menangkap, menelan, mencerna, dan menyimpan cadangan makanan yang cukup untuk mendukung metamorfosis tubuh menuju morfologi yang berbeda, yaitu tahap larva cyprid, yang tidak makan menyediakan energi untuk kegiatan cyprid berenang dan menjelajah, untuk pencarian dan identifikasi inang, pemukiman dan perlekatan mendukung metamorfosis ke bentuk morfologi selanjutnya. Berakhirnya proses ini, siklus hidup akan terus berulang. Metamorfosis Cirripedia diawali oleh larva cyprid yang berenang bebas. Metamorfosis mengarah pada pembentukan Juvenile Octolasmis di bawah carapas cyprid dengan ukuran lebih kecil daripada organisme dewasa. Larva Ciprid melakukan penetrasi ke dalam kutikula inang, dan menyuntikkan bahan parasit langsung ke haemolymph dari inang (KKP, 2010).

Octolasmis sp. merupakan parasit yang bersifat hermaprodit yang memiliki kedua jenis kelamin (Anderson, 1994). Dalam kondisi normal, ovarium menghasilkan telur di dalam peduncle dan akan membuahi kapitulum yang memiliki organ jantan. Telur akan matang dalam capitulum dan akan dilepaskan ke badan air sebagai nauplius setelah menetas. Proses penempelan akan terjadi jika nauplius menjadi larva cyprid dan tahapan cyprid ini akan ditemukan pada inang dalam hal ini kepiting (Ihwan et al., 2014).

Ketika dewasa, parasit ini akan melepaskan telurnya sehingga telurmya terbawa oleh air dan berenang bebas sampai menemukan substrat tempat menempel untuk berkembang biak. Oleh karena itu, untuk menunjang keberhasilan hidup sampai tahap dewasa maka larva cyprid ini harus mendapatkan tempat atau substrat yang sesuai agar dapat bertahan hidup sampai tahap dewasa dan siap bereproduksi kembali.

Menurut Zafran (1997), bahwa Ascarophis sp. termasuk dalam kelas Nematoda dan merupakan salah satu jenis parasit yang menyerang bagian luar tubuh organisme atau biasa disebut ektoparasit dan biasanya menginfeksi semua jenis organisme aquatik laut termsuk kepiting. Ascarophis sp. merupakan ektoparasit yang berukuran panjang dan kurus dengan segmen pada seluruh tubuhnya dan hidup bebas, ukuran panjang jantan $5 \mathrm{~mm}$ dan betina $8 \mathrm{~mm}$ Ascarophis sp. merupakan salah satu jenis parasit yang menyerang bagian luar tubuh baik insang maupun karapaks pada kepiting maupun lobster (Ratmin, 2002).

Hasil penelitian yang dilakukan oleh Poinar and Thomas (2011), menunjukkan bahwa infeksi Ascarophis sp. menyebabkan peningkatan angka kematian diantara kepiting dewasa dan dapat menurunkan pertumbuhan somatik inangnya. Penurunan berat rata-rata inang menunjukkan bahwa kerusakan jaringan akibat infeksi parasit ini bersifat aditif. Berat tubuh atau besarnya parasit Ascarophis sp dapat mengurangi kebugaran tubuh inang yang terinfeksi.

\section{Prevalensi dan Intenitas Parasit}

Parasit jenis Octolasmis sp dan Ascarophis sp. merupakan beberapa jenis parasit yang sering ditemukan menginfeksi kepiting bakau di daerah Bombana khususnya wilayah Desa Lantari Jaya. Hal ini dibuktikan dengan nilai prevalensi atau tingkat angka kejadian infeksi kedua jenis parasit yang ditemukan cukup tinggi yaitu antara $90-$ $100 \%$ untuk Octolasmis sp dan $50-96 \%$ untuk Ascarophis sp. Sebagaimana yang dikemukakan oleh Williams and Williams (1996) yang menyatakan bahwa nilai prevalensi parasit yang berkisar antara $90-100 \%$ merupakan nilai 
prevalensi yang tinggi dimana hal tersebut menggambarkan tingkat keseringan suatu jenis parasit yang ditemukan menginfeksi suatu inang.

Nilai intensitas parasit atau nilai rata-rata individu parasit yang menginfeksi inang memberikan gambaran akan kondisi atau level infeksi parasit. Berdasarkan data yang diperoleh, nilai intensitas ke dua jenis parasit tersebut adalah 93 - 151 (ind/ekor) inang untuk Octolasmis sp dan 69 - 120 (ind/ekor) inang untuk Ascarophis sp. Nilai intensitas tersebut termasuk dalam kategori nilai intensitas yang tinggi sebagaimana yang dikemukakan oleh Williams and Williams (1996) yang menyatakan bahwa nilai intensitas parasit yang berkisar antara 50 - 100 individu per ekor termasuk dalam kategori infeksi parasit yang berat.

Tingginya nilai prevalensi dan intensitas parasit bisa disebabkan oleh kondisi lingkungan yang sesuai untuk parasit dapat bertahan hidup, baik itu kondisi perairan seperti, suhu, salinitas dan lain sebagainya. Selain itu, ketersediaan nutrient yang diubutuhkan parasit untuk berkembangbiak juga menunjang hal terebut. Layaknya sebagai mahluk hidup, parasit juga membutuhkan lingkungan hidup yang sesuai agar dapat bertahan hidup berkembang biak layaknya organisme lain. Tak bisa diabaikan pula, keberadaan atau ketersediaan organisme lain yang layak untuk dijadikan inang bagi parasit adalah salah satu faktor keberhasilan parasit dalam bertahan hidup. Hal tersebut didukung oleh Nobel (1989) yang menyatakan bahwa distribusi parasit pada organ penempelnya dipengaruhi oleh suhu, kelembaban, sifat kimia media sekelilingnya dan persediaan makanan pada tubuh inang.

Di samping itu, ditemukan adanya perbedaan antara nilai intensitas dan nilai prevalensi parasit pada inang. Perbedaan tersebut adalah perbedaan yang terjadi ketika nilai instesitas parasit yang satu menurun maka intensitas parasit parasit yang lain akan meningkat. Fenomena ini diduga bisa disebabkan oleh proses infeksi dua jenis parasit atau lebih secara bersamaan akan mengurangi intensitas dan dominasi serangan parasit jenis yang lain karena proses kompetisi untuk tempat hidup dan kompetisi dalam memanfaatkan ketersediaan sumber makanan sehingga hanya akan ada satu jenis parasit saja yang mendominasi di satu inang. Hal tersebut didukung oleh pernyataan Noble and Noble (1989) bahwa infeksi bersama antar spesies akan menghambat perkembangan atau bahkan merugikan spesies yang lain.

\section{Akumulasi Merkuri (Hg) pada Kepiting Bakau}

Berdasarkan hasil yang didapatkan dari penelitian ini, nila total akumulasi merkuri pada kepiting bakau masih berada di bawah ambang batas normal sehingga masih aman dan layak untuk dikonsumsi oleh masyarakat. Hal ini dibuktikan dengan nilai akumulasi yang diperoleh setelah melakukan pemeriksaan pada setia sampel yang masih berada di bawah ambang batas. Hal ini sesuai dengan acuan pada peraturan pemerintah yang menyatakan bahwa standar nasional batas maksimum cemaran logam berat merkuri pada daging ikan dan olahannya adalah $0,5 \mathrm{mg} / \mathrm{kg}$ sedangkan pada udang dan krustase lainnya adalah $1,0 \mathrm{mg} / \mathrm{kg}$ (BSN, 2009).

Rendahnya kandungan logam berat tersebut bisa disebakan oleh rendahnya kandungan merkuri pada lingkungan tempat organisme hidup seperti pada air dan sedimen yang diduga sebagai salah satu sumber pencemaran merkuri bagi organisme di perairan. Hal ini bisa dibuktikan dengan nilai akumulasi yang didapatkan dari hasil penelitian dimana nilai akumulasi dari sampel air adalah $0,0003 \mathrm{mg} / \mathrm{l}$ sedagkan pada sedimen adalah 0,15 $\mathrm{mg} / \mathrm{kg}$.

Kisaran angka tersebut masih berada pada kisaran normal atau masih berada di bawah ambang batas sesuai dengan peraturan yang ditetapkan oleh pemerintah dalam Keputusan Menteri Negara Lingkungan Hidup Nomor 51 Tahun 2004 Tentang Baku Mutu Air Laut untuk kehidupan biota. Peraturan tersebut menjelaskan bahwa batas konsentrasi logam berat merkuri $(\mathrm{Hg})$ di perairan adalah $0,001 \mathrm{mg} / \mathrm{l}$.

Jika dilihat dari hasil pengujian beberapa parameter kualitas air, kondisi kualitas air di wilayah penelitian masih berada pada kisaran normal. Hal ini dibuktikan dengan nilai suhu, salinitas, kesadahan dan kondisi $\mathrm{pH}$ yang berada dalam kondisi normal dan layak bagi organisme untuk bertahan hidup. Di samping itu, kondisi parameter kualitas air tersebut tidak mempengaruhi toksisitas atau berbagai reaksi kimia yang dapat terjadi di perairan yang dapat meningkatkan atau menurunkan toksisitas suatu logam berat khususnya merkuri yang ada di perairan karena beberapa parameter kualitas air tersebut masih berada dalam kondisi normal sehingga tidak terjadi reaksi kimia 
8 Erik Arjuna Aris et al.

JURNAL SAINS dan INOVASI PERIKANAN/ Journal of Fishery Science and Innovation

Vol. 2, No. 1, 1-9, Januari 2018

tertentu yang dapat mempangaruhi level atau tingkatan toksisitas logam berat yang ada di perairan.

Tabel 2. Hasil pemeriksaan kualitas air

\begin{tabular}{|c|c|c|c|c|}
\hline \multirow[t]{2}{*}{$\begin{array}{l}\text { Para- } \\
\text { meter }\end{array}$} & \multirow[t]{2}{*}{$\begin{array}{l}\text { Satu- } \\
\text { an }\end{array}$} & \multicolumn{2}{|c|}{$\begin{array}{c}\text { Hasil } \\
\text { Pengukuran }\end{array}$} & \multirow[t]{2}{*}{ Nilai Optimal } \\
\hline & & $\mathbf{I}$ & II & \\
\hline $\mathrm{pH}$ & - & 6 & 6 & $\begin{array}{c}\text { 6-9 (PP. No. } \\
82 \text { Tahun } \\
\text { 2001) }\end{array}$ \\
\hline Suhu & ${ }^{0} \mathrm{C}$ & $\begin{array}{c}28- \\
30\end{array}$ & $\begin{array}{c}28- \\
30\end{array}$ & $\begin{array}{c}23-32{ }^{0} \mathrm{C} \\
\text { (Fujaya, 2008) }\end{array}$ \\
\hline Salinitas & ppt & 26 & 0 & $\begin{array}{c}25-35 \mathrm{ppt} \\
\text { (Cahyono } \\
d k k ., 2006)\end{array}$ \\
\hline $\begin{array}{l}\text { Kesadah } \\
\text { an }\end{array}$ & $\mathrm{mg} / \mathrm{l}$ & 130,5 & 90.08 & $\begin{array}{l}\text { Stickney } \\
(1979)\end{array}$ \\
\hline
\end{tabular}

Hutagalung (1984) dalam tulisannya berpendapat bahwa faktor lingkungan perairan seperti $\mathrm{pH}$, kesadahan, suhu dan salinitas juga turut mempengaruhi toksisitas logam berat. Penurunan $\mathrm{pH}$ air menyebabkan toksisitas logam berat makin besar. Sebagai contoh, toksisitas nikel sianida $(\mathrm{NiCN})$ berubah menjadi 1000 kali lebih toksik bila pH turun sebanyak 1,5 (Doudoroff et al., 1966 dalamEnvironmental Protection Agency 1975). Kesadahan yang tinggi dapat mengurangi toksisitas logam berat. karena logam berat dalam air dengan kesadahan yang tinggi membentuk senyawa kompleks yang mengendap dalam air. Kisaran kesadahan yang dibutuhkan untuk keperluan perikanan adalah berkisar antara nilai $20-150 \mathrm{mg} / \mathrm{L}$ CaCO3 (Stickney, 1979). Untuk parameter $\mathrm{pH}$, Berdasarkan Peraturan Pemerintah Nomor 82 tahun 2001, untuk parameter $\mathrm{pH}$ nilai antara $6-9$ adalah kriteria air kelas satu, yang dapat dimanfaatkan untuk berbagai keperluan seperti wisata air, perikanan, peternakan dan lain-lain.

\section{KESIMPULAN}

Keimpulannya adalah Jenis parasit yang dominan menginfeksi kepiting bakau (Scylla spp) pada penelitian ini adalah Ascarophis sp dan Octolasmis sp dengan nilai prevalensi (50 $100 \%)$ dan intensitas (69 - 150 ind/ekor) yang masuk dalam kategori tinggi. Terjadi akumulasi
(Hg) pada organisme kepiting bakau (Scylla sp) yang hidup di alam meskipun kandungan $\mathrm{Hg}$ di alam (air dan sedimen) masih tergolong rendah. Kandungan logam berat pada kepiting bakau masih berada di bawah ambang batas sesuai peraturan yang berlaku sehingga masih layak dan aman untuk dikonsumsi oleh masyarakat.

\section{DAFTAR PUSTAKA}

BAPELDA Pontianak. 2007. Laporan Hasil Pemantauan Merkuri pada Air Sungai Kapuas di Kalimantan Barat. Kalimantan Barat

Cahyono I, Muhammad I, Suwiryono. 2006. Studi of Empowering Soft Shelling Crab. Farmers in South Sulawes. Takalar: Brackishwater Aquaculture Development Center, South Galesong.

EPA (Environmental Protection Agency). 1973. Water Quality Criteria. Washington: Ecologycal Research Seriea. pp595.

Fujaya Y, Trijuno DD. 2008. Haemolymph Ecdysteroid Profile of Mud Crab During Molt and Reproductive Cycles. Torani 17 (5) : 415421.

Huspeni TC, Lafferty KD. 2004. Using larval trematodes that parasitize snails to evaluate a salt-marsh restoration project. Ecological Application14:795-804.

Hutagalung PH. 1984. Logam Berat Dalam Lingkungan Laut. Pusat Penelitian Ekologi, Lembaga Oseanologi Nasional - LIPI, Jakarta. Jurnal Oseana IX (1) : 11-20.

Ismarti, Fitrah A, Ramses. 2015. Kandungan Logam Berat $\mathrm{Pb}$ dan $\mathrm{Cd}$ pada Sedimen dan kerang di Perairan Batam. Jurnal Dimensi 23: 12-19.

Murtini JT, Peranginangin R. 2006. Kandungan Logam Berat pada Kerang Kepah (Meritrix meritrix) dan Air Laut di Perairan Banjarmasin. Jurnal Perikanan (J.Fish.Sci.) VIII (2) : 177184.

Peraturan Pemerintah. 2001. Peraturan Pemerintah Republik Indonesia Nomor 82 Tahun 2001. Tentang Pengelolaan Kualitas Air dan Pengendalian Pencemaran Air.

Poinar GO, Thomas GM. 2011. Occurrence of Ascarophis (Nematoda: Spiruridea) in Callianassa californiensis Dana and Other 
Vol. 2, No. 1, 1-9, Januari 2018

Decapod Crustaceans. California: Division of Entomology and Parasitology, University of California; and The Bodega Marine Laboratory, University of California.

Rompas RM. 2010. Toksikologi Kelautan. Jakarta: Sekretariat Dewan Kelautan Indonesia. 338hal.

Sures B. 2004. Environmental parasitology, relevancy of parasites in monitoring environmental pollution. Trends in Parasitology 20:170-177.

Sures B. 2006. How parasitism and pollution affect the physiological homeostasis of aquatic hosts. Journal of Helminthology 80: 151-158.

Ugokwe CU, Awobode HO. 2015. Heavy metals in organs and endoparasites of Oreochromis niloticus, Sediment and Water from River Ogun, Ogun State, Nigeria. IOSR Journal of Environmental Science, Toxicology and Food Technology (IOSR-JESTFT) 9 (11)

Vidal-Martinez VM, Pech D, Sures B, Purucker ST, Poulin R. 2009. Can parasites really reveal environmental impact? Trends in Parasitology 26: 44-49.

Widodo FI. 2012. Dampak Pencemaran Merkuri terhadap Biota Air dan Kesehatan Manusia. Jurnal Lingkungan Hidup .http://uwityangyoyo.wordpress. com (diakses tanggal 30 Januari 2015)

Williams EHJ, Williams LB. 1996. Parasites of Offshore Big Game Fishes of Puerto Rico and The Western Atlantic. Puerto Rico: Department of Natural and Environmental Resources dan University of Puerto Rico. 383 p. 